\title{
Cigarette smoke extract induces the proliferation of normal human urothelial cells through the $\mathrm{NF}-\kappa \mathrm{B}$ pathway
}

\author{
QI-FEI DENG ${ }^{1 *}$, XIN SUN $^{1 *}$, ZHAO-FENG LIANG $^{2}$, ZHI-QIANG ZHANG $^{1}$, \\ DE-XIN YU ${ }^{1}$ and CAI-YUN ZHONG ${ }^{2}$ \\ ${ }^{1}$ Department of Urology, The Second Affiliated Hospital of Anhui Medical University, Hefei, Anhui 230032; \\ ${ }^{2}$ Department of Nutrition and Food Safety, School of Public Health, Nanjing Medical University, \\ Nanjing, Jiangsu 211166, P.R. China
}

Received October 25, 2015; Accepted December 7, 2015

DOI: $10.3892 /$ or.2016.4623

\begin{abstract}
Bladder cancer is a common genitourinary malignant disease worldwide. Convincing evidence shows that cigarette smoke (CS) is a crucial risk factor for bladder cancer, yet the role of the $\mathrm{NF}-\kappa \mathrm{B}$ signaling pathway in the development of CS-associated bladder cancer has not been fully elucidated. In the present study, we found that exposure to cigarette smoke extract (CSE) induced proliferation and triggered the transition of normal human urothelial cells from G1 to S phase. Moreover, CSE exposure enhanced the expression of cyclin D1 and proliferating cell nuclear antigen (PCNA) and decreased the expression of p21 in SV-HUC-1 cells. Furthermore, the levels of nuclear NF- $\kappa$ B p 65/p50 were significantly elevated by CSE. Pre-treatment with the NF- $\kappa \mathrm{B}$ inhibitor (PDTC) reversed CSE-triggered cell proliferation. Taken together, our study revealed that CSE induced proliferation of normal human urothelial cells through the NF- $\mathrm{BB}$ pathway, and these data enhance our understanding of the CSE-related carcinogenesis of bladder cancer.
\end{abstract}

Correspondence to: Professor De-Xin Yu, Department of Urology, The Second Affiliated Hospital of Anhui Medical University, 80 Feicui Road, Hefei, Anhui 230032, P.R. China

E-mail: yudx_urology@126.com

Dr Cai-Yun Zhong, Department of Nutrition and Food Safety, School of Public Health, Nanjing Medical University, 818 East Tianyuan Road, Nanjing, Jiangsu 211166, P.R. China

E-mail: cyzhong@njmu.edu.cn

*Contributed equally

Abbreviations: SV-HUC-1, SV-40 immortalized human uroepithelial cell line; CS, cigarette smoke; CSE, cigarette smoke extract; MTT, thiazolyl blue tetrazolium bromide; RT-PCR, reverse transcription-polymerase chain reaction

Key words: cell proliferation, bladder cancer, cigarette smoke extract, NF- $\mathrm{KB}$ pathway

\section{Introduction}

Bladder cancer is the 11th most common cancer worldwide, accounting for an estimated 429,793 new diagnosed cases and 165,084 deaths each year $(1,2)$. Bladder cancer is becoming the leading cause of cancer-related death among all urinary malignancies (3-5).

Cigarette smoke (CS) is a well-established risk factor for bladder cancer $(3,6,7)$. Zeegers et al concluded that cigarette smokers have an approximately 3-fold higher risk of bladder cancer (8), and it has been estimated that CS accounts for $50 \%$ of bladder cancer cases among both men and women (9). CS contains at least 60 carcinogens such as cigarette-specific nitrosamines, specific polycyclic aromatic hydrocarbons (PAHs), and multiple alkylated agents which are capable of initiating tumorigenesis (10-12). There have been many epidemiological investigations of CS, but there is limited research on the mechanism of CS leading to bladder cancer.

Accumulating evidence has confirmed that the deregulation of the cell cycle in normal cells is central to cancer initiation (13). The constituents of CS can impact cell cycle progression and proliferation, and accelerate tumor progression in multiple cancer types, including bladder cancer $(14,15)$. Ho et al demonstrated that exposure to nicotine increased the expression of cyclin D1 and proliferating cell nuclear antigen (PCNA) via the nuclear factor $-\kappa \mathrm{B}(\mathrm{NF}-\kappa \mathrm{B})$ signaling pathway (16). Other researchers found that upon exposure to cigarette smoke extract (CSE) the expression levels of p21 and p27 were significantly reduced $(17,18)$.

There are five members of the NF- $\kappa \mathrm{B}$ family: p50/p105

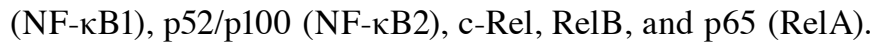
In most cell types, $\mathrm{NF}-\kappa \mathrm{B}$ complexes exist as homodimeric and heterodimeric, which are predominantly cytoplasmic and transcriptionally inactive by the inhibitory protein I $\mathrm{B}$ mainly $\mathrm{I} \kappa \mathrm{B} \alpha$. In response to environmental stimuli, the I $\kappa \mathrm{B}$ proteins then undergo rapid ubiquitination and proteasome-mediated degradation by $\mathrm{I} \kappa \mathrm{B}$ kinases (IKK) and releasing complex to translocate to the nucleus and alter gene transcription $(19,20)$. $\mathrm{NF}-\kappa \mathrm{B}$ plays an essential role in cell proliferation and cancer development (21-24), and regulates the expression of cell cycle genes, such as cyclin D1 and c-myc $(19,25)$. However, little information is available in regards to the role of $N F-\kappa B$ 
activity in CSE-induced proliferation of normal human urothelial cells.

The present study aimed to investigate the proliferative effect of CSE on normal human urothelial SV-HUC-1 cells. Moreover, the role of NF- $\mathrm{NB}$ activity in CSE-induced proliferation in these cells was also explored.

\section{Materials and methods}

Materials. An SV-40 immortalized human urothelial cell line (SV-HUC-1) was purchased from the Chinese Academy of Typical Culture Collection Cell Bank. F12K medium was purchased from Gibco (New York, NY, USA). Fetal bovine serum (FBS) was obtained from PAA Laboratories (Pasching, Austria). 3-(4,5-Dimethylthiazol-2-yl)-2,5diphenyltetrazolium bromide (MTT) was purchased from Sigma-Aldrich. p-IKK $\alpha / \beta$, IкB, p65, p21, cyclin D1, PCNA antibodies were all purchased from Cell Signaling Technology (Beverly, MA, USA). P50 was purchased from Santa Cruz Biotechnology (Santa Cruz, CA, USA). Primers were synthesized according to published sequences from Invitrogen (Carlsbad, CA, USA). Ammonium pyrrolidinedithiocarbamate (PDTC) was purchased from Beyotime (Shanghai, China). A nuclear and cytoplasmic protein extraction kit was purchased from KeyGen (Nanjing, China). Sources of other materials are noted accordingly in the text.

Cell culture and treatment. The SV-HUC-1 cells were cultured in F12K medium with $10 \%$ FBS and antibiotics $(100 \mathrm{U} / \mathrm{ml}$ penicillin and $100 \mu \mathrm{g} / \mathrm{ml}$ streptomycin) in a humidified atmosphere of $5 \% \mathrm{CO}_{2}$ at $37^{\circ} \mathrm{C}$. The medium was changed every other day. When the cells reached $80-90 \%$ confluency, they were treated with various concentrations of cigarette smoke extract (CSE) or with PDTC ( $2 \mu \mathrm{M})$ for 7 days.

Preparation of the cigarette smoke extract. CSE was prepared daily immediately before use according to a previously reported method (26). Briefly, one filterless 3R4F reference cigarette (12 $\mathrm{mg}$ tar and $1.0 \mathrm{mg}$ nicotine/cigarette) was combusted, and the mainstream smoke was continuously drawn through a glass syringe containing $10 \mathrm{ml}$ of FBS-free F12K that was pre-warmed to $37^{\circ} \mathrm{C}$ at a rate of $5 \mathrm{~min} /$ cigarette. The resulting suspension was adjusted to $\mathrm{pH} 7.4$ and then filtered through a $0.22-\mu \mathrm{m}$-pore size filter. The obtained solution was referred to as a $100 \%$ CSE solution and was further diluted to the desired concentration with culture medium. Control solution was prepared using the same protocol, except that the cigarette was unlit. SV-HUC-1 cells were exposed to various concentrations of CSE within $30 \mathrm{~min}$ of preparation.

MTT assay. Briefly, SV-HUC-1 cells (1x103/well) were seeded in 96-well plates with F12K medium containing $10 \%$ FBA for up to $24 \mathrm{~h}$. The cells were treated with different concentrations of CSE for 7 days. Cells viability was measured by MTT assay. Twenty microliters of MTT solution $(5 \mathrm{mg} / \mathrm{ml})$ was added to each well, and the plates were further incubated for $4 \mathrm{~h}$ at $37^{\circ} \mathrm{C}$. Then the MTT was removed and the precipitants were solubilized in DMSO. Absorbance was measured at $490 \mathrm{~nm}$ using a microplate reader. All measurements were performed in triplicate.
Cell cycle analysis. The distribution of SV-HUC-1 cells at different stages in the cell cycle was calculated by flow cytometric analysis. Briefly, we plated $1 \times 10^{6}$ cells on $6-\mathrm{cm}$ dishes for $24 \mathrm{~h}$. Then the cells were incubated at $37^{\circ} \mathrm{C}$ overnight. SV-HUC-1 cells were treated with $0,0.1,0.25$, and $0.5 \%$ CSE for 7 days and then trypsinized and washed twice with cold PBS and mixed with $75 \%$ ethanol at $4^{\circ} \mathrm{C}$ overnight. Then the cells were centrifuged and resuspended in $500 \mu 1$ PBS. After addition of $10 \mu \mathrm{l}$ RNAse $(10 \mathrm{mg} / \mathrm{ml})$, the cells were left for $30 \mathrm{~min}$ at $37^{\circ} \mathrm{C}$ in the dark and stained with $10 \mu 1$ propidium iodide $(1 \mathrm{mg} / \mathrm{ml})$. The cells were immediately evaluated by flow cytometry. The percentages of cells in each cell cycle phase (G0/G1, S, G2/M) were measured using Multicycle V.3.0 software, with a minimum of $1 \times 10^{5}$ cells/sample being evaluated.

Quantitative reverse transcription-polymerase chain reaction ( $q R T-P C R)$. For RNA analysis, $1 \times 10^{6}$ cells per dish were plated in $6-\mathrm{cm}$ plastic tissue culture dishes for $24 \mathrm{~h}$. Then SV-HUC-1 cells were either exposed to different concentrations of CSE, or were pretreated for 30 min with PDTC $(2 \mu \mathrm{M})$ before exposure to CSE for 7 days. Finally, the cells were harvested, and total RNA was extracted using TRIzol reagent (Invitrogen) according to the manufacturer's protocol. Total RNA was reverse-transcribed using the Easy RT-PCR kit according to the manufacturer's instructions. GAPDH was analyzed in parallel as an internal control. Real-time PCR assays were performed using Power SYBR Green Master Mix and an ABI 7300 real-time PCR detection system (both from Applied Biosystems, USA). The primer sequences used for the RT-PCR were: cyclin D1 forward, 5'-CGTGGCCTCTAAGATGAA GG-3' and reverse, 5'-TGCGGATGATCTGTTTGTTC-3'; p21 forward, 5'-GACACCACTGGAGGGTGACT-3' and reverse, 5'-CAGGTCCACATGGTCTTCCT-3'; and GAPDH forward, 5'-GCTGCCCAACGCACCGAATA-3' and reverse 5'-GAGT CAACGGATTTGGTCGT-3'. All of the primers were synthesized by RiboBio (Guangzhou, China). Fold changes in expression of each gene were calculated by a comparative threshold cycle $(\mathrm{Ct})$ method using the formula $2^{-(\Delta \Delta \mathrm{Ct})}$.

\section{Preparation of nuclear and cytoplasmic protein extraction.} The NF- $\kappa \mathrm{B}$ activity in the nuclear and cytoplasmic fractions was determined using the KeyGen kit (KeyGen, Nanjing, China) according to the instructions of the manufacturer. Briefly, cultured cells were collected by centrifugation, washed in cold PBS three times and suspended in $100 \mu \mathrm{l}$ of buffer A (containing DTT $1 \mathrm{mM}$ and PMSF $0.5 \mathrm{mM}$ ) and incubated on ice for $15 \mathrm{~min}$. Then $5 \mu \mathrm{l}$ of buffer was added to the suspension and briely vortexed. Following this, the nuclear proteins were pelleted by centrifugation at low speed. The (cytoplasmic extract) supernatant was collected and stored at $-20^{\circ} \mathrm{C}$. The nuclear pellet was resuspended in $50 \mu \mathrm{l}$ of buffer $\mathrm{C}$ (containing DTT $1 \mathrm{mM}$ and PMSF $0.5 \mathrm{mM}$ ). The suspension was incubated for $30 \mathrm{~min}$ at $4^{\circ} \mathrm{C}$ and volatility every $10 \mathrm{~min}$ to $15 \mathrm{sec}$ followed by centrifugation at $16,000 \mathrm{x} \mathrm{g}$ for $10 \mathrm{~min}$. The supernatant containing the nuclear protein extract was transferred to a fresh microcentrifuge tube and stored at $-20^{\circ} \mathrm{C}$.

Western blot analysis. Western blot analyses were used for assessment of the protein levels of NF- $\mathrm{NB}$ p65, p50, 
$\mathrm{I} \kappa \mathrm{B} \alpha, \mathrm{p}-\mathrm{IKK} \alpha / \beta$, cyclin D1, p21 and PCNA. Cytosolic or nuclear proteins (40-60 $\mu \mathrm{g}$ ) were loaded and separated on $10 \%$ SDS-PAGE and were transferred to PVDF membranes (Millipore, Billerica, MA, USA). After blocking with 5\% milk, the membranes were subsequently probed with primary antibodies at a dilution of 1:500 for $12 \mathrm{~h}$ at $4^{\circ} \mathrm{C}$, and then incubated with the secondary antibodies at a dilution of 1:1,000. Finally, the membranes were developed using an enhanced chemiluminescence detection kit (Amersham Biosciences, USA) and exposed to film. GAPDH was used as a loading control.

Statistical analysis. All data are presented as mean \pm standard deviation. Statistical analyses were performed by one-way analysis of variance, using SPSS 17.0. A value of $\mathrm{P}<0.05$ was considered statistically significant, All of the experiments were performed in triplicate and performed at least thrice to confirm their reproducibility.

\section{Results}

CSE induces the proliferation of SV-HUC-1 cells. The growth of normal bladder epithelial cells (SV-HUC-1) was detected by MTT assay at various concentrations of CSE $(0,0.05,0.1,0.25$, $0.5,0.75,1.0,2.0$ and $4.0 \%$ ) for 7 days. As shown in Fig. 1, CSE caused a significant increase in cell viability at concentrations from 0.05 to $0.5 \%$. Therefore, CSE concentrations of $0.1,0.25$, and $0.5 \%$ were selected in our following experiments.

CSE triggers cell cycle progression in SV-HUC-1 cells. In order to investigate the effect of CSE on the cell cycle, we used flow cytometry to analyze the proportion of cells in each phase. As shown in Fig. 2A and B, flow cytometry showed that treatment with $0.5 \% \mathrm{CSE}$ accelerated G1 to S phase progression, with $40.87 \%$ of cells entering into the $S$ phase, which was significantly higher than that of the control value (13.86\%). The effect was in a dose-related manner. The results demonstrated that exposure of SV-HUC-1 cells to CSE induced proliferation by modulating cell cycle distribution. As shown in Fig. $2 \mathrm{C}$, western blot analysis showed that CSE exposure increased the cyclin D1 and PCNA protein expression level and decreased the p21 protein expression level. As shown in Fig. 2D, results of qRT-PCR revealed that CSE exposure enhanced the level of mRNA expression of cyclin D1, while the expression level of p21 was significantly decreased.

CSE activates the NF- $\kappa B$ pathway in SV-HUC-1 cells. To determine whether the CSE-induced proliferation is correlated with the $\mathrm{NF}-\kappa \mathrm{B}$ pathway, we examined the protein levels of p65 and p50 in the nuclear extract of the SV-HUC-1 cells (Fig. 3A). The nuclear protein levels of both p65 and p50 were significantly increased. Furthermore, we also examined the upstream of the NF- $\mathrm{B}$ pathway. As shown in Fig. 3B, the expression of I $\mathrm{B}$ kinase (p-IKK $\alpha / \beta)$ was clearly increased in the cytoplasm, and IкB was subsequently degradation and the expression was obviously reduced.

Inhibition of $N F-\kappa B$ reverses $C S E$-induced $S V-H U C-1$ cell proliferation. To further determine the effect of the altered $\mathrm{NF}-\kappa \mathrm{B}$ signaling pathway activity on CSE-induced SV-HUC-1 cell proliferation, the inhibition of the $\mathrm{NF}-\kappa \mathrm{B}$ pathway with

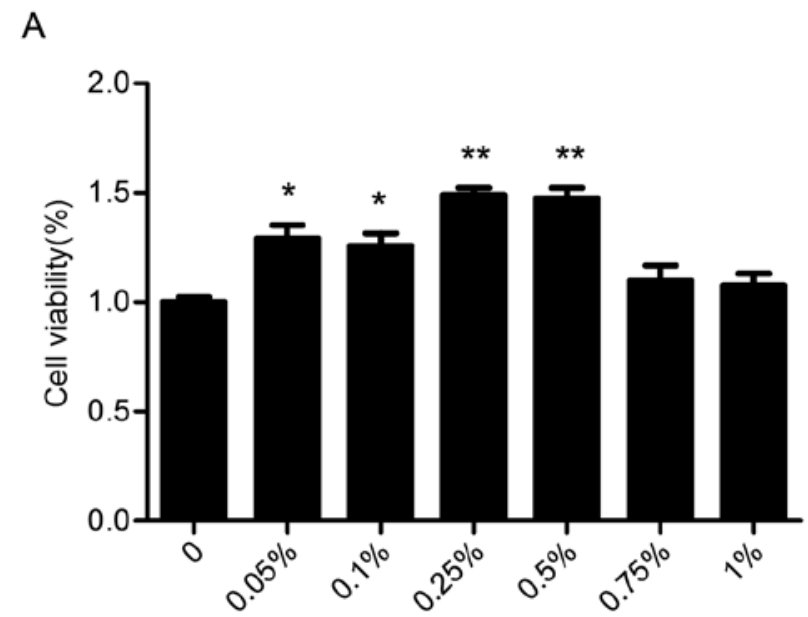

Cigarette smoke extract(\%)

B

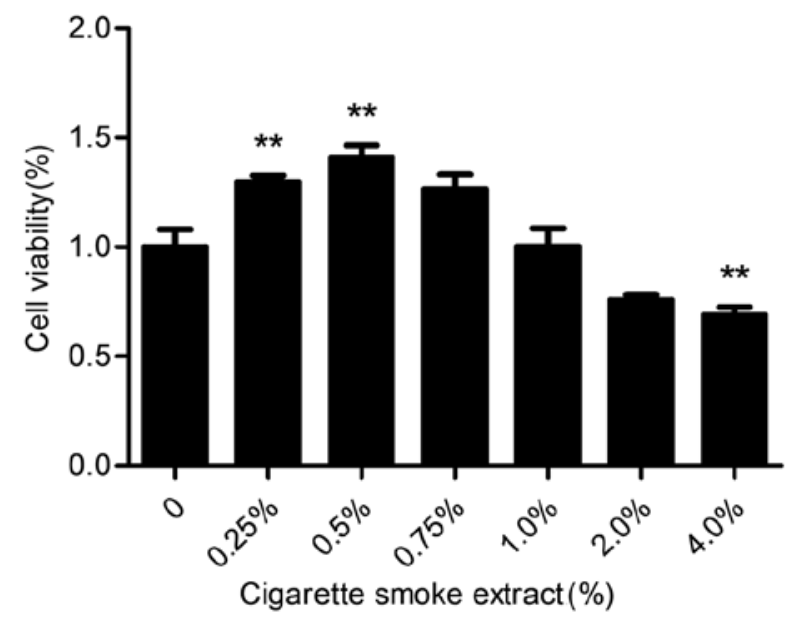

Figure 1. Cigarette smoke extract (CSE) induces SV-HUC-1 cell proliferation. (A) Effect of CSE on the cell viability of SV-HUC-1 cells. SV-HUC-1 cells were treated with various concentrations of CSE for 7 days and cell viability was measured by the MTT assay. (B) Effect of CSE on the cell viability of SV-HUC-1 cells at higher concentrations. Data are expressed as mean $\pm \mathrm{SD} .{ }^{*} \mathrm{P}<0.05,{ }^{* *} \mathrm{P}<0.01$, compared with the control group.

ammonium pyrrolidinedithiocarbamate (PDTC, $2 \mu \mathrm{M}$ ), a $\mathrm{NF}-\kappa \mathrm{B}-\mathrm{specific}$ inhibitor was used to pretreat the cells. As shown in Fig. 4A, an MTT assay was executed to test the cell viability and the inhibitory effect of the inhibitor. As shown in Fig. 4B and C, the western blot results showed that the activities of p65 and p50 proteins were significantly reduced. This confirmed that the NF- $\kappa \mathrm{B}$ pathway was effectively inhibited. As shown in Fig. $5 \mathrm{~A}$ and $\mathrm{B}$, flow cytometry revealed that inhibition of the $\mathrm{NF}-\kappa \mathrm{B}$ pathway decreased the percentage $(16.71 \%)$ of cells in the $\mathrm{S}$ phase as compared with the control (43.33\%). As shown in Fig. 5C, cyclin D1 and PCNA protein levels were downregulated and accordingly the effect on p21 was reversed, when activation of the $\mathrm{NF}-\kappa \mathrm{B}$ pathway was inhibited. In addition, as shown in Fig. 5D, qRT-PCR showed that the cyclin D1 mRNA level was decreased following inhibition of the NF- $\kappa \mathrm{B}$ pathway, consistent with the change in the protein level. Inhibition of the $\mathrm{NF}-\kappa \mathrm{B}$ pathway reversed the effect of CSE on the SV-HUC-1 cells. These data suggest that 
A

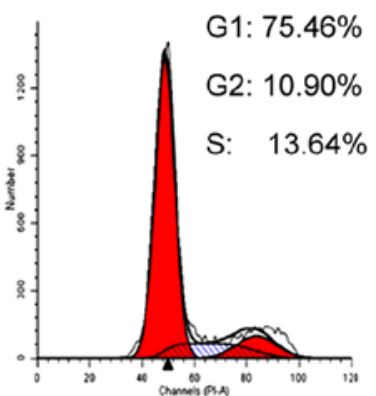

$0 \%$

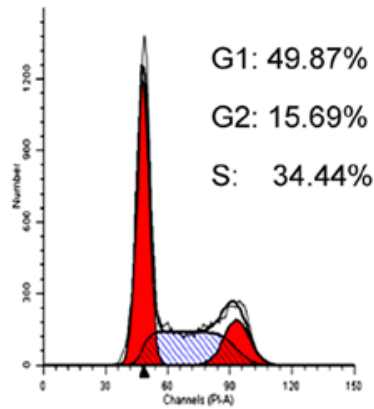

$0.25 \%$
B

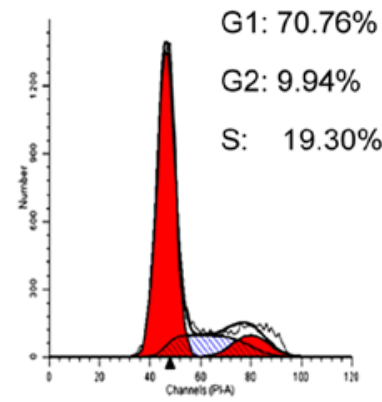

$0.1 \%$

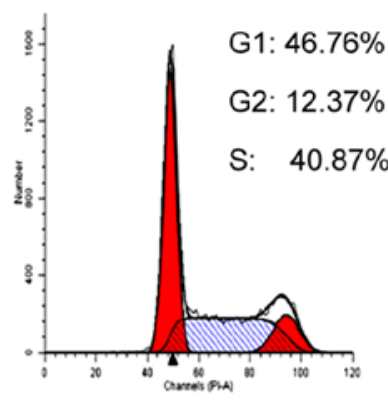

$0.5 \%$

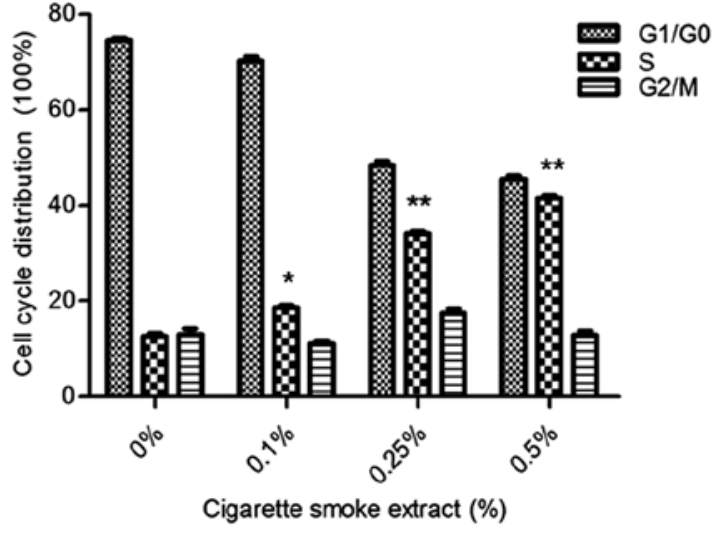

Cigarette smoke extract (\%)

C

cyclin D1

P21

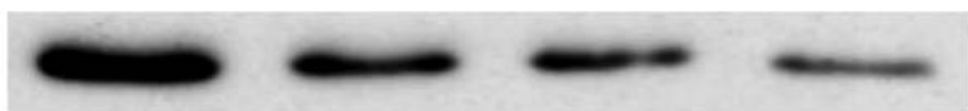

PCNA
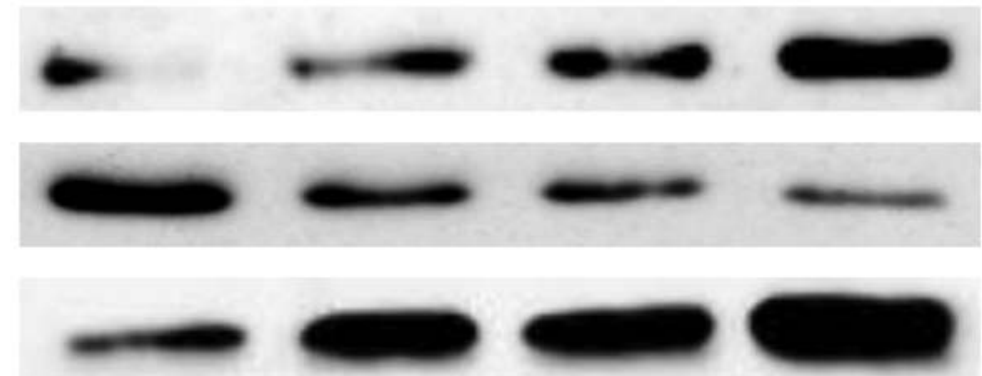

GAPDH

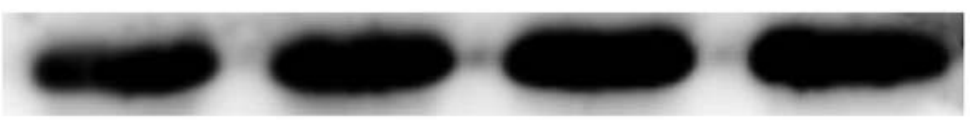

$0 \%$

$0.1 \%$

$0.25 \%$

$0.5 \%$

$\mathrm{D}$
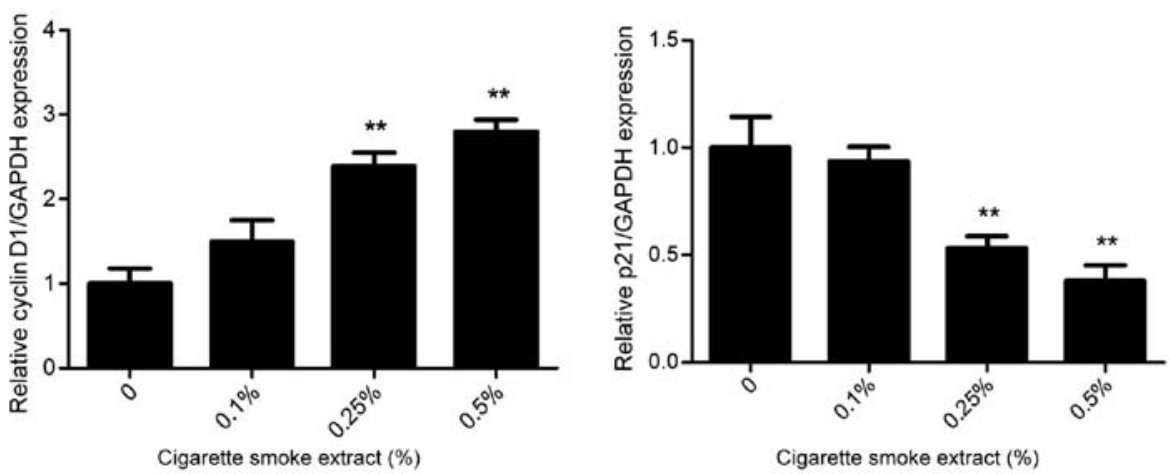

Figure 2. Cigarette smoke extract triggers cell cycle progression in SV-HUC-1 cells. (A and B) SV-HUC-1 cells were treated with CSE for 7 days, cells were fixed in $70 \%$ ethanol, and cell cycle analysis was performed by flow cytometry. One representative image of more than three independent experiments is shown. Data are expressed as mean $\pm \mathrm{SD} .{ }^{*} \mathrm{P}<0.05,{ }^{* *} \mathrm{P}<0.01$, compared with the control group. (C and D) Cigarette smoke extract alters cell cycle marker expression in SV-HUC-1 cells. (C) Cigarette smoke extract increased the protein expression of cyclin D1 and PCNA and decreased protein expression of p21 as determined by western blotting. Glyceraldehyde 3-phosphate dehydrogenase was used as a loading control. (D) Cigarette smoke extract increased the expression of cyclin D1 mRNAs, and decreased the expression of p21 mRNAs, as detected by quantitative reverse transcriptase-polymerase chain reaction after normalization to glyceraldehyde 3-phosphate dehydrogenase. One representative image of more than three independent experiments is shown. Data are expressed as mean $\pm \mathrm{SD}$. ${ }^{*} \mathrm{P}<0.05,{ }^{* * *} \mathrm{P}<0.01$, compared with the control group. 
A

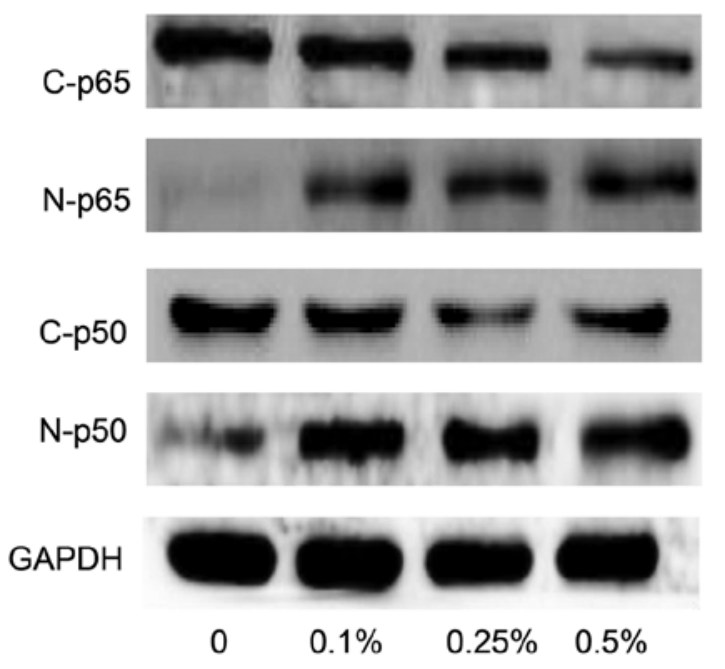

B
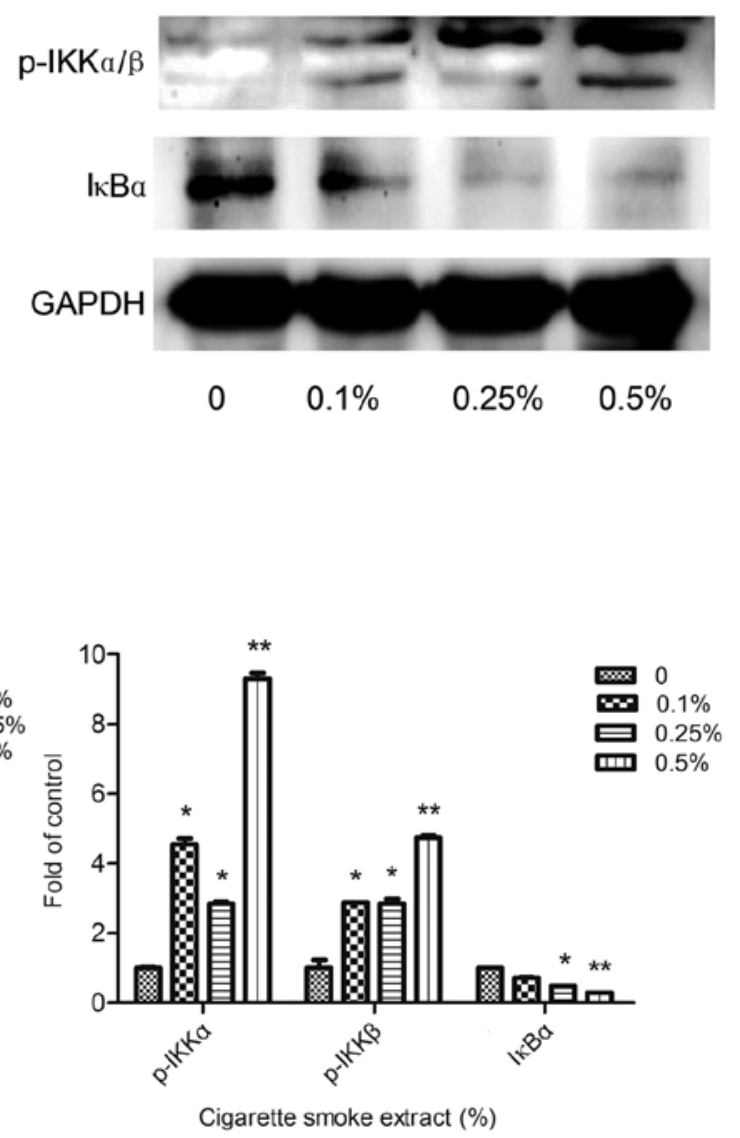

Figure 3. CSE-induced cell proliferation is associated with NF- $\kappa \mathrm{B}$ activation in the SV-HUC-1 cells. (A) CSE caused NF- $\mathrm{B}$ activation in the SV-HUC-1 cells. The levels of nuclear p50 and p65 were increased. The active form of NF- $\kappa$ B was measured by western blotting following CSE treatment. (B) CSE increased IKK protein activation, while I $\mathrm{B}$ was subsequently degradation. Glyceraldehyde 3-phosphate dehydrogenase was used as loading control. One representative image of more than three independent experiments is shown. Data are expressed as mean $\pm \mathrm{SD}$. ${ }^{*} \mathrm{P}<0.05,{ }^{* *} \mathrm{P}<0.01$, compared with the control group.

the NF- $\mathrm{B}$ pathway plays an important role in CSE-induced proliferation of normal human urothelial SV-HUC-1 cells.

\section{Discussion}

The hypothesis that CS is closely related to the development of bladder cancer is supported by studies with rodents, non-human primates and human cancer cell lines (8-12). The underlying molecular mechanisms by which CS causes bladder cancer development remain to be established. In the present study, we revealed that exposure to CSE induced cell proliferation in normal human urothelial SV-HUC-1 cells. Most importantly, we showed that CSE-induced cell proliferation was reversed by $N F-\kappa B$ inhibition. These data suggest the important role of NF- $\kappa \mathrm{B}$ activity in CSE-associated cell proliferation and provide critical information in regards to the molecular mechanisms of CSE-related bladder tumorigenesis as well as the identification of a potential target of bladder cancer intervention.

Dysregulation of the cell cycle and unlimited proliferation play an important role in initiation of tumorigenesis $(28,29)$. Evidence has revealed that exposure of cells to carcinogens induce dysregulation of the cell cycle $(14,30,31)$, suggesting the important role of dysregulation of the cell cycle in the initiation of tumorigenesis. Schaal and Chellappan demonstrated that exposure of non-neuronal cells to tobacco carcinogen nicotine induced dysregulation of the cell cycle, and early precancerous lesions during the tumorigenic process, participating in cancer initiation and promoting the clonal expansion of premalignant cells (14). It has been documented that CS promoted the progression of the cell cycle, resulting in loss of growth inhibition which increased the potential of limitless replication (32-34). In agreement with previous studies, we showed in the present study that exposure of SV-HUC-1 cells to CSE induced proliferation by modulating cell cycle distribution. Compared with the control group (13.64\%), CSE induced cell proliferation as determined by MTT assay and the percentage of cells in the S phase $(40.87 \%)$ was increased significantly in the CSE-treated group. Moreover, we also showed that CSE exposure resulted in increased expression of PCNA and cyclin D1, as well as decreased expression of p21 in normal human urothelial SV-HUC-1 cells, suggestive of proliferation induction. Take together; our data revealed that CSE triggered proliferation in normal human urothelial cells. 
A

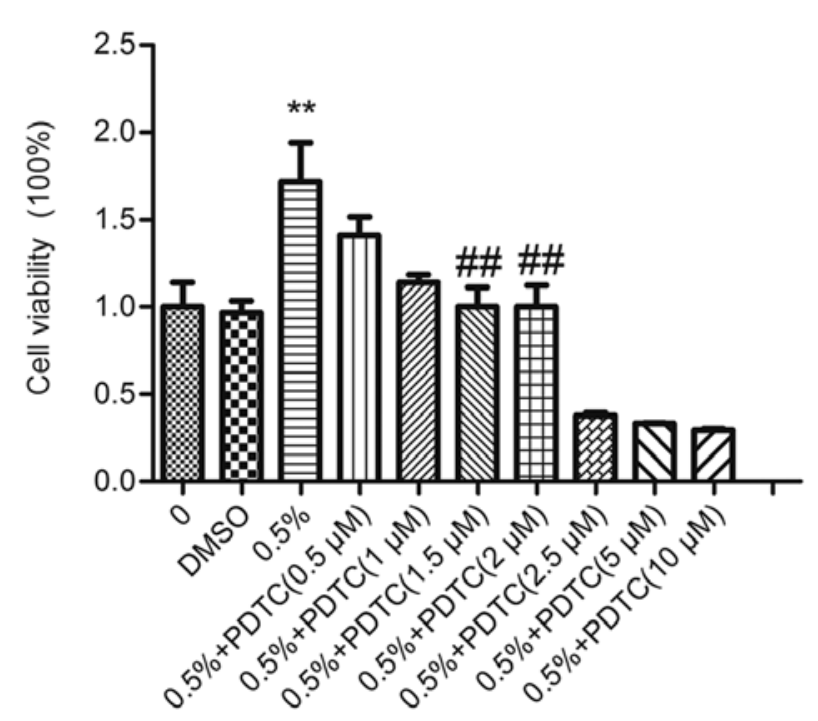

Cigarette smoke extract (\%)
B
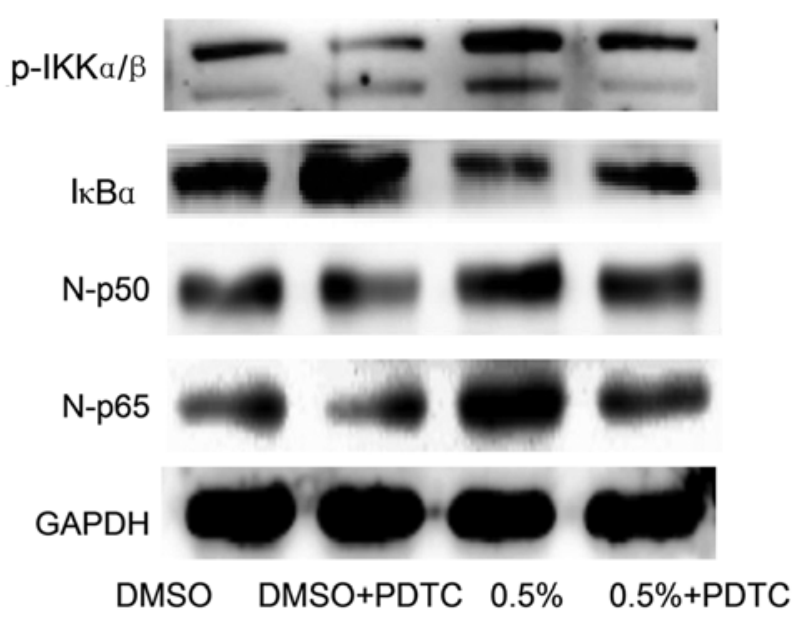

C
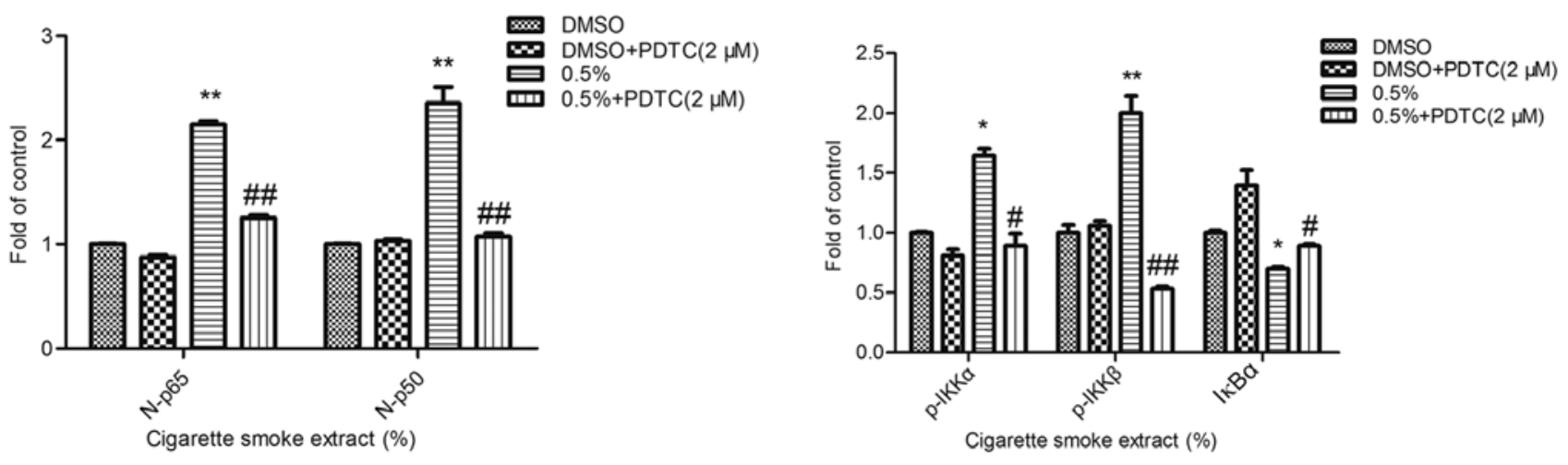

Figure 4. Proliferative effect of CSE on SV-HUC-1 cells is reversed when cells are treated with the NF-kB pathway inhibitor. (A) SV-HUC-1 cells were treated with $0.5 \%$ CSE with or without $2 \mu \mathrm{M}$ PDTC for 7 days, and cell viability was measured by MTT assay. Data are expressed as mean \pm standard deviation (SD). ${ }^{*} \mathrm{P}<0.05$, compared with the control group. (B) Activation of NF- $\mathrm{KB}$ was obviously inhibited by PDTC. (C) Densitometric analyses of the western blotting. ${ }^{*} \mathrm{P}<0.05,{ }^{* * *} \mathrm{P}<0.01$, compared with the control group; ${ }^{\#} \mathrm{P}<0.05,{ }^{\# \#} \mathrm{P}<0.01$, compared with the PDTC control group.

To explore the molecular mechanisms of CSE-induced proliferation, the role of the NF- $\mathrm{KB}$ pathway in regulating CSE-mediated cell proliferation was investigated in our study. A large number of reports have demonstrated that NF- $\kappa B$ regulates cell proliferation (35-38). Many studies revealed that $\mathrm{NF}-\kappa \mathrm{B}$ can directly regulate cell cycle genes and trigger the expression of proliferation-related proteins, such as cyclin D1, PCNA and p21 (39,40). Cyclin D1 forms active holoenzymes with CDK4 or CDK6 by phosphorylating the retinoblastoma protein (pRB) to play an important role in regulating transition from the G1 phase to the S phase in the cell cycle $(41,42)$. Cyclin D1 expression is regulated by NF- $\kappa B$ (42). Proliferating cell nuclear antigen (PCNA) plays a crucial role in modulating DNA replication and cell proliferation in AML cells (44). Moreover, PCNA can also serve as a potential chemotherapy target (45). The cyclin dependent kinase inhibitor p21 is a negative regulator of the cell cycle through inactiving Cdks and directly interacts with PCNA to inhibit replication. A close relationship between NF- $\mathrm{KB}$ and $\mathrm{p} 21$ has been demonstrated (46). In line with these previous studies, we found that CSE-induced NF- $\kappa \mathrm{B}$ activation was associated with downregulation of p21, and upregulation of cyclin D1 and PCNA. In addition, we also showed in the present study that CSE increased the levels of phosphorylated IKK and reduced

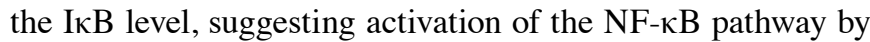
CSE. Meanwhile, we found that inhibition of NF- $\kappa B$ activity reversed CSE-induced proliferation in SV-HUC-1 cells. Collectively, our data indicated that the NF- $\mathrm{KB}$ pathway positively regulates CSE-induced proliferation in SV-HUC-1 cells.

In summary, we demonstrated that exposure of normal human urothelial SV-HUC-1 cells to cigarette smoke extract induced cell proliferation. Moreover, NF- $\kappa \mathrm{B}$ activity played an important role in CSE-triggered cell proliferation. The findings of this study provide new insight into the molecular mechanisms of cigarette smoke-related bladder cancer carcinogenesis. 
A
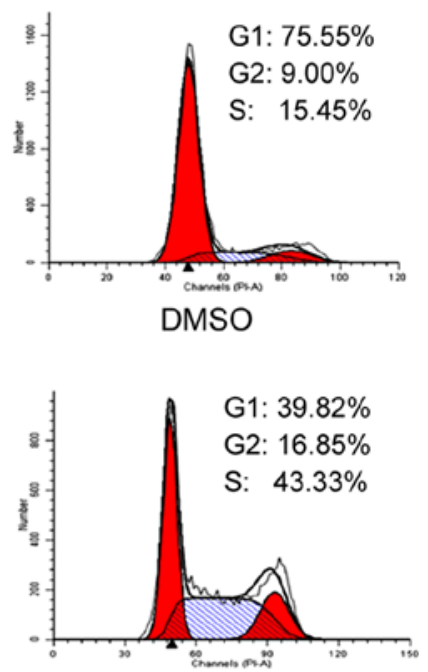

$0.5 \%$ CS

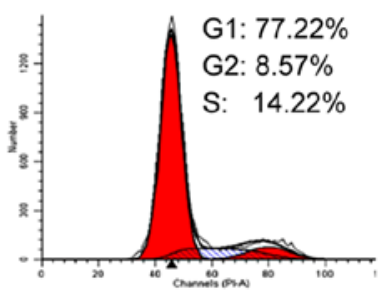

DMSO+PDTC (2 $\mu \mathrm{M})$

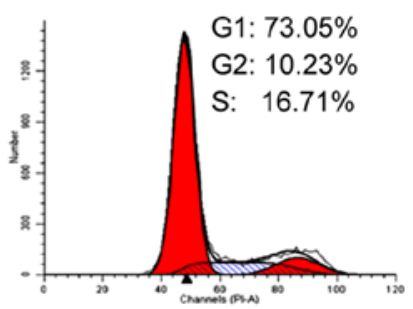

$0.5 \%+$ PDTC $(2 \mu \mathrm{M})$
B

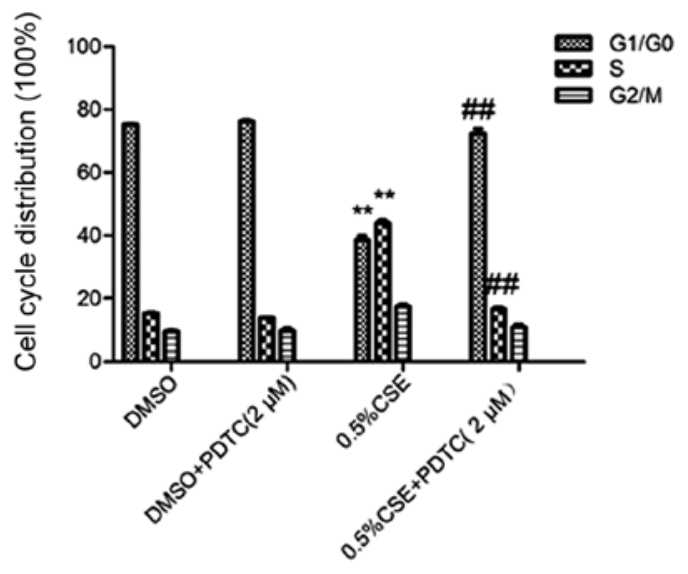

C

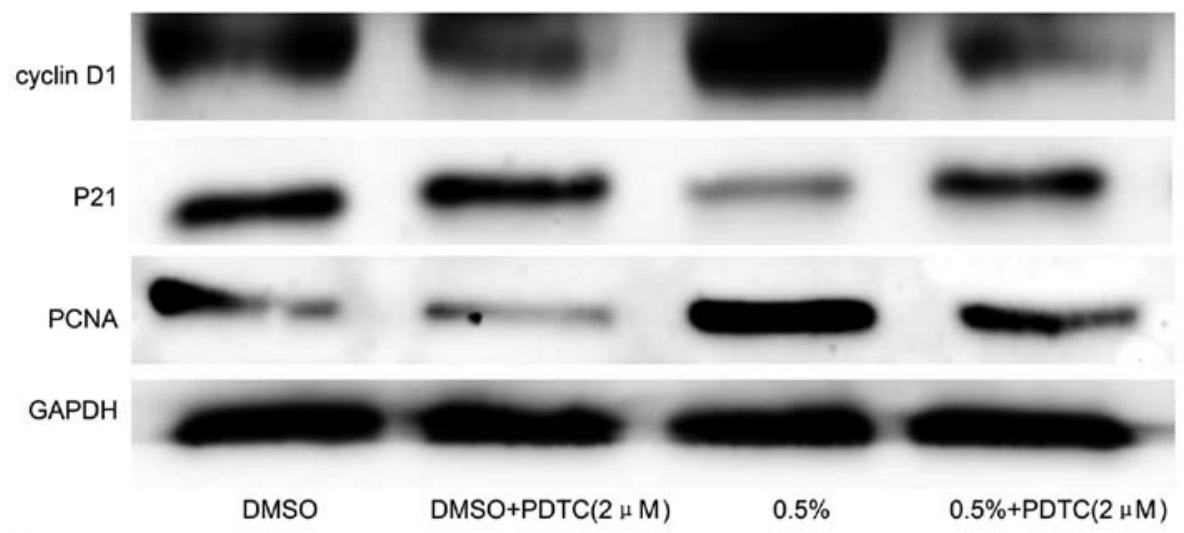

D
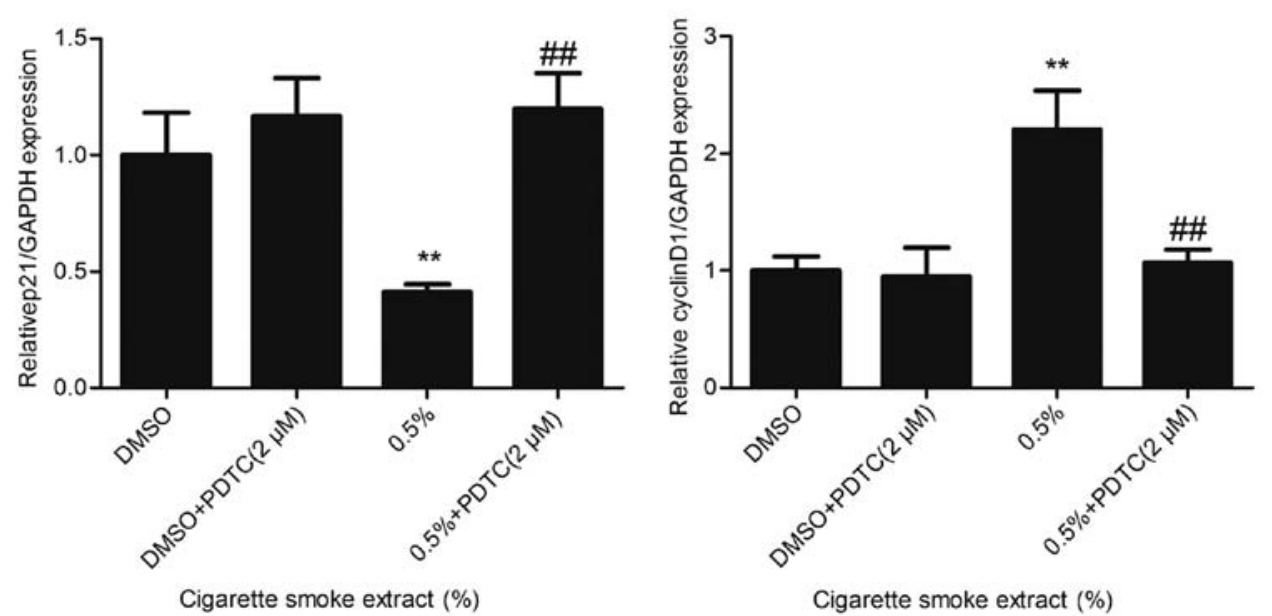

Figure 5. Inhibition of NF- $\mathrm{kB}$ reverses CSE-induced SV-HUC-1 cell cycle progression. (A and B) SV-HUC-1 cells were treated with $0.5 \%$ CSE with or without $2 \mu \mathrm{M}$ PDTC for 7 days. Cell cycle progression was entirely inhibited. ${ }^{*} \mathrm{P}<0.05,{ }^{* *} \mathrm{P}<0.01$, compared with the control group; ${ }^{*} \mathrm{P}<0.05$, ${ }^{\# \#} \mathrm{P}<0.01$, compared with the PDTC control group. (C and D) Inhibition of NF- $\mathrm{kB}$ reverses CSE-induced SV-HUC-1 cell cycle marker expression. SV-HUC-1 cells were treated with 0.5\% CSE with or without $2 \mu \mathrm{M}$ PDTC for 7 days. Cell cycle marker expression was entirely reversed. ${ }^{*} \mathrm{P}<0.05,{ }^{* *} \mathrm{P}<0.01$, compared with the control group; ${ }^{\sharp} \mathrm{P}<0.05$, ${ }^{\# \#} \mathrm{P}<0.01$, compared with the PDTC control group.

\section{Acknowledgements}

This study was supported by grants from the National Natural
Science Foundation of China (nos. 81373005, 81072330, and 81202194) and by the Priority Academic Program Development of Jiangsu Higher Education Institutions (PAPD). 


\section{References}

1. Ferlay J, Shin HR, Bray F, Forman D, Mathers C and Parkin DM: GLOBOCAN 2008, Cancer incidence and mortality worldwide: IARC CancerBase No. 10. [Internet] International Agency for Research on Cancer, Lyon, France, 2010. Available from http:// globocan.iarc.fr. Accessed May 6, 2012.

2. Ferlay J, Soerjomataram I, Dikshit R, Eser S, Mathers C, Rebelo M, Parkin DM, Forman D and Bray F: Cancer incidence and mortality worldwide: Sources, methods and major patterns in GLOBOCAN 2012. Int J Cancer 136: E359-E386, 2015.

3. Burger M, Catto JW, Dalbagni G, Grossman HB, Herr H, Karakiewicz P, Kassouf W, Kiemeney LA, La Vecchia C, Shariat $\mathrm{S}$, et al: Epidemiology and risk factors of urothelial bladder cancer. Eur Urol 63: 234-241, 2013.

4. Jemal A, Bray F, Center MM, Ferlay J, Ward E and Forman D: Global cancer statistics. CA Cancer J Clin 61: 69-90, 2011.

5. Torre LA, Bray F, Siegel RL, Ferlay J, Lortet-Tieulent $J$ and Jemal A: Global cancer statistics, 2012. CA Cancer J Clin 65: 87-108, 2015.

6. Letašiová S, Medve'ová A, Šovčíková A, Dušinská M, Volkovová K, Mosoiu C and Bartonová A: Bladder cancer, a review of the environmental risk factors. Environ Health 11 (Suppl 1): S11, 2012.

7. Boffetta P: Tobacco smoking and risk of bladder cancer. Scand J Urol Nephrol Suppl 218: 45-54, 2008.

8. Zeegers MP, Tan FE, Dorant E and van Den Brandt PA: The impact of characteristics of cigarette smoking on urinary tract cancer risk: A meta-analysis of epidemiologic studies. Cancer 89: 630-639, 2000

9. Freedman ND, Silverman DT, Hollenbeck AR, Schatzkin A and Abnet CC: Association between smoking and risk of bladder cancer among men and women. JAMA 306: 737-745, 2011.

10. Hecht SS: Tobacco smoke carcinogens and lung cancer. J Natl Cancer Inst 91: 1194-1210, 1999.

11. Phillips DH: Smoking-related DNA and protein adducts in human tissues. Carcinogenesis 23: 1979-2004, 2002.

12. Hecht SS: Tobacco carcinogens, their biomarkers and tobacco-induced cancer. Nat Rev Cancer 3: 733-744, 2003.

13. Sobus SL and Warren GW: The biologic effects of cigarette smoke on cancer cells. Cancer 120: 3617-3626, 2014.

14. Schaal C and Chellappan SP: Nicotine-mediated cell proliferation and tumor progression in smoking-related cancers. Mol Cancer Res 12: 14-23, 2014.

15. Cardinale A, Nastrucci C, Cesario A and Russo P: Nicotine: Specific role in angiogenesis, proliferation and apoptosis. Crit Rev Toxicol 42: 68-89, 2012.

16. Ho YS, Chen CH, Wang YJ, Pestell RG, Albanese C, Chen RJ, Chang MC, Jeng JH, Lin SY and Liang YC: Tobacco-specific carcinogen 4-(methylnitrosamino)-1-(3-pyridyl)-1-butanone (NNK) induces cell proliferation in normal human bronchial epithelial cells through NFkappaB activation and cyclin D1 up-regulation. Toxicol Appl Pharmacol 205: 133-148, 2005.

17. Shin VY, Jin HC, Ng EK, Yu J, Leung WK, Cho CH and Sung JJ: Nicotine and 4-(methylnitrosamino)-1-(3-pyridyl)-1-butanone induce cyclooxygenase- 2 activity in human gastric cancer cells: Involvement of nicotinic acetylcholine receptor (nAChR) and beta-adrenergic receptor signaling pathways. Toxicol Appl Pharmacol 233: 254-261, 2008.

18. Norton JD: ID helix-loop-helix proteins in cell growth, differentiation and tumorigenesis. J Cell Sci 113: 3897-3905, 2000.

19. Aggarwal BB: Nuclear factor-kappaB: The enemy within. Cancer Cell 6: 203-208, 2004.

20. Orlowski RZ and Baldwin AS Jr: NF-kappaB as a therapeutic target in cancer. Trends Mol Med 8: 385-389, 2002.

21. Bassères DS and Baldwin AS: Nuclear factor-kappaB and inhibitor of kappaB kinase pathways in oncogenic initiation and progression. Oncogene 25: 6817-6830, 2006.

22. Hoesel B and Schmid JA: The complexity of NF- $\mathrm{BB}$ signaling in inflammation and cancer. Mol Cancer 12: 86, 2013.

23. Lin Y, Bai L, Chen W and Xu S: The NF-kappaB activation pathways, emerging molecular targets for cancer prevention and therapy. Expert Opin Ther Targets 14: 45-55, 2010.

24. Dobrovolskaia MA and Kozlov SV: Inflammation and cancer: When NF-kappaB amalgamates the perilous partnership. Curr Cancer Drug Targets 5: 325-344, 2005.

25. Guttridge DC, Albanese C, Reuther JY, Pestell RG and Baldwin AS Jr: NF-kappaB controls cell growth and differentiation through transcriptional regulation of cyclin D1. Mol Cell Biol 19: 5785-5799, 1999.
26. Gál K1, Cseh A, Szalay B, Rusai K, Vannay A, Lukácsovits J, Heemann U, Szabó AJ, Losonczy G, Tamási L, Müller V: Effect of cigarette smoke and dexamethasone on Hsp72 system of alveolar epithelial cells. Cell Stress Chaperones 16: 369-378, 2011.

27. Alguacil J, Kogevinas M, Silverman DT, Malats N, Real FX, García-Closas M, Tardón A, Rivas M, Torà M, García-Closas R, et al: Urinary $\mathrm{pH}$, cigarette smoking and bladder cancer risk. Carcinogenesis 32: 843-847, 2011.

28. Baldi A, De Luca A, Esposito V, Campioni M, Spugnini EP and Citro G: Tumor suppressors and cell-cycle proteins in lung cancer. Patholog Res Int 2011: 605042, 2011.

29. Crawford JM: The origins of bladder cancer. Lab Invest 88: 686-693, 2008

30. Li X, Xie W, Xie C, Huang C, Zhu J, Liang Z, Deng F, Zhu M, Zhu W,Wu R, et al: Curcumin modulates miR-19/PTEN/AKT/p53 axis to suppress bisphenol A-induced MCF-7 breast cancer cell proliferation. Phytother Res 28: 1553-1560, 2014.

31. Bishop RK, Valle OC and Spencer JV: Human cytomegalovirus interleukin-10 promotes proliferation and migration of MCF-7 breast cancer cells. Cancer Cell Microenviron 2: e678, 2015.

32. Li T, Song T, Ni L, Yang G, Song X, Wu L, Liu B and Liu C: The p-ERK-p-c-Jun-cyclinD1 pathway is involved in proliferation of smooth muscle cells after exposure to cigarette smoke extract. Biochem Biophys Res Commun 453: 316-320, 2014.

33. Massagué J: G1 cell-cycle control and cancer. Nature 432: 298-306, 2004.

34. Hanahan D and Weinberg RA: Hallmarks of cancer: The next generation. Cell 144: 646-674, 2011.

35. Yao J, Zhao L, Zhao Q, Zhao Y, Sun Y, Zhang Y, Miao H, You QD, Hu R and Guo QL: NF- $\kappa$ B and Nrf2 signaling pathways contribute to wogonin-mediated inhibition of inflammation-associated colorectal carcinogenesis. Cell Death Dis 5: e1283, 2014.

36. Alvira CM: Nuclear factor-kappa-B signaling in lung development and disease: One pathway, numerous functions. Birth Defects Res A Clin Mol Teratol 100: 202-216, 2014.

37. Li J, Yan M, Wang Z, Jing S, Li Y, Liu G, Yu J and Fan Z: Effects of canonical NF- $\mathrm{kB}$ signaling pathway on the proliferation and odonto/osteogenic differentiation of human stem cells from apical papilla. Biomed Res Int 2014: 319651, 2014.

38. Perkins ND: The diverse and complex roles of NF- $\kappa \mathrm{B}$ subunits in cancer. Nat Rev Cancer 12: 121-132, 2012.

39. Helisch A, Förster GJ, Reber H, Buchholz HG, Arnold R, Göke B, Weber MM, Wiedenmann B, Pauwels S, Haus U, et al: Pre-therapeutic dosimetry and biodistribution of 86Y-DOTA-Phe1-Tyr3-octreotide versus 111In-pentetreotide in patients with advanced neuroendocrine tumours. Eur J Nucl Med Mol Imaging 31: 1386-1392, 2004.

40. Kim HJ, Hawke N and Baldwin AS: NF-kappaB and IKK as therapeutic targets in cancer. Cell Death Differ 13: 738-747, 2006.

41. Zhang XY, Xu YJ, Liu XS and Zhang ZX: Cigarette smoke extract promotes proliferation of airway smooth muscle cells in asthmatic rats via regulating cyclin D1 expression. Chin Med J (Engl) 123: 1709-1714, 2010.

42. Musgrove EA, Caldon CE, Barraclough J, Stone A and Sutherland RL: Cyclin D as a therapeutic target in cancer. Nat Rev Cancer 11: 558-572, 2011.

43. Hinz M, Krappmann D, Eichten A, Heder A, Scheidereit C and Strauss M: NF-kappaB function in growth control: Regulation of cyclin D1 expression and G0/G1-to-S-phase transition. Mol Cell Biol 19: 2690-2698, 1999.

44. Villar HO, Uyeno ET, Toll L, Polgar W, Davies MF and Loew GH: Molecular determinants of benzodiazepine receptor affinities and anticonvulsant activities. Mol Pharmacol 36: 589-600, 1989.

45. Morgan RG,Ives SJ,LesniewskiLA,CawthonRM,AndtbackaRH, Noyes RD, Richardson RS and Donato AJ: Age-related telomere uncapping is associated with cellular senescence and inflammation independent of telomere shortening in human arteries. Am J Physiol Heart Circ Physiol 305: H251-H258, 2013.

46. Chung S, Sundar IK, Hwang JW, Yull FE, Blackwell TS, Kinnula VL, Bulger M, Yao H and Rahman I: NF- $\kappa$ B inducing kinase, NIK mediates cigarette smoke/TNF $\alpha$-induced histone acetylation and inflammation through differential activation of IKKs. PLoS One 6: e23488, 2011. 